\title{
Comparative Analysis of Chemical Compounds Related to Quality of Canned Asparagus
}

\author{
Sara María Jaramillo-Carmona, Francisco Javier Tejero-Maján, Ana Jiménez-Araujo, \\ Rafael Guillén-Bejarano, Rocío Rodríguez-Arcos* \\ Phytochemicals and Food Quality Group, Instituto de la Grasa, Consejo Superior de Investigaciones Científicas (CSIC), \\ Campus Universitario Pablo de Olavide, Edificio 46, Ctra de Utrera Km 1, Sevilla-41013, Spain \\ *Corresponding author: rrodri@ig,csic.es
}

Received January 06, 2019; Revised February 11, 2019; Accepted February 25, 2019

\begin{abstract}
Asparagus cultivation and consumption are widely spread throughout the world. Several investigations about fresh asparagus have evidenced that they are a nutritionally well-balanced and one of the best sources of antioxidants being the green spears richer than the white ones. However, there is scarce information on quality of canned asparagus. In the present work, we have studied chemical and phytochemical composition of 21 distinct presentations of asparagus, representative of the distinct brands available in Spanish markets. Our results revealed that this appreciated product continued to be of high nutritional quality after industrial processing, containing 1-1.8\% bioactive fiber and 1-3\% proteins. In addition, it contained significant quantities of several bioactive compounds, mainly ascorbic acid (6-12 mg/100g) and phenolics that in green asparagus ranged $16-46 \mathrm{mg} / 100 \mathrm{~g}$. Asparagus variety seems to be the factor that most influence the composition and quality of the final product. There were two samples of green asparagus that stand out from all others and that correspond to triguero asparagus from southern Spain. It can be concluded that the selection of varieties taking into account not only agronomic factors, but also phytochemical profile is determinant to obtain a product of the highest quality for both fresh and processed commercialization.
\end{abstract}

Keywords: canned asparagus, white and green spears, asparagus variety, chemical composition, nutritional quality, bioactive compounds

Cite This Article: Sara María Jaramillo-Carmona, Francisco Javier Tejero-Maján, Ana Jiménez-Araujo, Rafael Guillén-Bejarano, and Rocío Rodríguez-Arcos, "Comparative Analysis of Chemical Compounds Related to Quality of Canned Asparagus." Journal of Food and Nutrition Research, vol. 7, no. 2 (2019): 171-182. doi: 10.12691/jfnr-7-2-10.

\section{Introduction}

Asparagus has traditionally widely prized by its exquisite organoleptic properties, being also increasingly considered for its nutritional and functional quality. Asparagus spears are available in the market in green and white form. White asparagus is more popular in Asia and Europe, while green asparagus is preferred in America. This plant food is well suited not only for fresh use, but also for freezing and canning; being the last the most commercialized presentation. It is also possible to find some varieties of wild asparagus (triguero) in our markets, but they are usually consumed in the local area of production and mostly commercialized in fresh.

Nutritionally, asparagus provides very few calories, about $22 \mathrm{Kcal} / 100 \mathrm{~g}$, but it is an important source of distinct nutrients, such as proteins, amino acids and dietary fiber. Asparagus edible portion contains a high amount of water, which varied from $92 \%$ in green spears to $95 \%$ in the white ones. Therefore, the contribution of macronutrients highlighted in asparagus, such as fiber and proteins, does not exceed 3-4\% in any case. Asparagus proteins are of high quality due their composition in essential amino acids [1], and the bioactive fiber is of great interest for its physico-chemical and functional properties [2].

In addition, the edible portion of the spears is an excellent source of vitamin $\mathrm{K}$, folate, vitamin $\mathrm{B} 2$, vitamin $\mathrm{C}$, and vitamin $\mathrm{E}$, niacin, vitamin $\mathrm{A}$, vitamin $\mathrm{B} 6$, and pantothenic acid. It is also a very good source of copper, selenium, manganese, phosphorus, potassium, choline, zinc, iron, magnesium and calcium. In fact, asparagus is considered as one of the twelve more healthy vegetables. One serving of cooked asparagus (180 g) provides 101\% of the Daily Recommended Intake (DRI) of vitamin K, and also $67 \%$ DRI of folate, 33\% DRI of copper, and near $20 \%$ DRI of vitamins B1, B2, C and E and selenium [3].

Currently it is more than well established that green vegetables are nutritionally well-balanced and they enjoy much attention for the beneficial effects on human health, many of them derived from their antioxidant contents. Regarding this subject, it has been reported that among the vegetables commonly consumed in the United States and Europe, asparagus is the richest in total quality and 
quantity of antioxidants, what places it at the top among functional foods of plant origin [4,5].

Although asparagus composition is affected by many factors, such as environmental conditions, variety and cultivation techniques, there are general differences between white and green asparagus spears. With the exception of sugars, the composition of green asparagus is higher than that of white. Ascorbic acid content is usually twice higher in green than in white asparagus [6], and the former are also one of the best plant sources of glutathione. There are no many references on triguero asparagus nutritional value, but there have been pointed that the nutritional and functional quality of triguero asparagus are greater than those of cultivated Asparagus officinalis. Hence, a comparative study between wild asparagus (Asparagus acutifolius) and a commercial cultivar of A. officinalis revealed that the first contained twice proteins, three more times essential amino acids and five more times ascorbic acid [7]. Asparagus is one of the most consumed wild vegetables, especially in rural areas of the Mediterranean basin. Recently, some studies have been conducted whose results suggest that there could be a close relationship between the good health of these rural communities and the contribution of essential nutrients and antioxidants provided by the consumption of these wild vegetables. The investigation of the nutritional and antioxidant properties of the most consumed wild vegetables in Iberian Peninsula traditional diet revealed that asparagus contained the highest levels of tocopherols, in of all its isoforms, and ascorbic acid. The authors of the study proposed that these components could play a significant role in potential health promoting effects by combating micronutrient deficiencies in human diets and providing an excellent source of antioxidants related to the prevention of several diseases [8].

Among the different phytochemicals present in asparagus, saponins and phenolics are the main responsible of their several physiological effects on human health. Asparagus saponins are steroidal glycosides, with protodioscin being the most abundant,although significant differences have been found on saponin profile from distinct green asparagus genotypes [9]. Several activities of asparagus saponins have been described, being of special interest the cytotoxicity against several lines of human cancerous cells $[10,11]$. Saponin levels increased from the tip to the basal portions of the spears, whereas phenolics are mainly located in the upper portions, so they may play a more relevant role in the beneficial effects associated to asparagus consumption. Flavonoids have very strong antioxidant activity. Additionally, they have antitumoral and antimicrobial activities, and participate in the prevention of cardiovascular diseases [12,13]. Asparagus spears also contain significant amounts of hydroxycinnamic acids linked to the fiber, especially ferulic acid that also contribute to antioxidant activity $[14,15,16]$ and thus to the prevention of disorders linked to oxidative stress, including Alzheimer's disease, diabetes, cancers, hypertension, therosclerosis, inflammatory diseases, and others [17].

Most investigations on asparagus composition have been made from fresh samples and there are a very few references on phytochemical composition of canned asparagus. In general, processing might cause a significant reduction in the antioxidant capacity, affecting the global quality of the final product [18]. Many efforts are being made in the last years in order to optimize the industrial processing and develop new methods of preservation that allow to maintain to a great extension the nutritional quality of canned asparagus. A recent research about the losses of antioxidant capacity of 25 of the most commonly consumed vegetables, after their processing and subsequent storage during 18 months, showed that asparagus quality was well maintained in the final product [19]. In this context, the main objective of the present study is to investigate the chemical composition and nutritional quality of canned asparagus available in Spanish markets and determine if there are differences in function of several factors, such as spear color, variety and origin of the samples.

\section{Materials and Methods}

\subsection{Samples}

White and green canned asparagus were purchased from the local supermarkets. The samples consisted on 10 samples of green asparagus and 11 from white asparagus that represent the commercial brands most widely commercialized in Spain. Asparagus spears were weighed, frozen at $-20^{\circ} \mathrm{C}$, and freeze-dried. This material was ground in a hammer mill to a particle size lower than $1 \mathrm{~mm}$ and stored at $-20^{\circ} \mathrm{C}$ until analysis. Asparagus canning liquid was also stored at $-20^{\circ} \mathrm{C}$ for further analysis.

\subsection{Ethanolic Extracts}

Soluble components from asparagus spears, such as sugars and flavonoids, were quantified from the ethanolic extract obtained by treatment of asparagus samples with $90 \% \mathrm{EtOH}$ in solid/solvent ratio of 1:4 (g of fresh sample/mL of ethanol). The samples were blended in a Thermomix Vorwerk, Model TM31 (Vorwerk, Spain), at maximum speed for $1 \mathrm{~min}$, and then filtered through filter paper. Ethanolic extracts were stored at $-20^{\circ} \mathrm{C}$ until HPLC analysis. All extractions were made in duplicate.

\subsection{Moisture}

Water content was determined by using a MB45 Moisture Analyzer (Ohaus Europe, Nänikon, Suiza). Samples, 1g, were dried to constant weight, setting the temperature at $105^{\circ} \mathrm{C}$. Analyses of moisture were conducted in triplicate.

\subsection{Soluble Sugar Quantification}

Ethanolic extracts were evaporated to dryness, under reduced press, and re-dissolved in distilled water for soluble sugar quantification. The samples were analyzed in a Dionex (Sunnyvale, CA, USA) high-performance anion-exchange chromatograph (HPAEC) using a Carbopac PA-10 column (4 x $250 \mathrm{~mm}, 10 \mu \mathrm{m})$ in combination with a Carbopac PA guard column ( 4 x $50 \mathrm{~mm}, 10 \mu \mathrm{m})$. The mobile phase consisted on $100 \mathrm{mM} \mathrm{NaOH}$ (eluent A) and $100 \mathrm{mM} \mathrm{NaOH}$ and $700 \mathrm{mM}$ sodium acetate (eluent B). The elution conditions were as follows: 0-15 min, $100 \%$ A (re-equilibration); injection at $15 \mathrm{~min}$ and start 
acquisition at $16 \mathrm{~min}$; linear gradient over $20 \mathrm{~min}$ to $75 \%$ A, 25\% B; held isocratically at 75\% A, 25\% B for further $15 \mathrm{~min}$. The flow rate was maintained at $0.9 \mathrm{~mL} / \mathrm{min}$. A Dionex pulsed electrochemical detector in the pulsed amperometric detection (PAD) mode was used. Sugar quantitation was made from the calibration curves with standards (glucose, fructose, and sucrose).

\subsection{Dietary Fibre}

Total dietary fibre was determined by enzymaticgravimetric method [20]. After digestion, four volumes of hot ethanol were added and the suspensions of soluble fibre were left overnight at $4^{\circ} \mathrm{C}$ to allow soluble fibre to precipitate. Afterwards, fibre was recovered by centrifugation for $20 \mathrm{~min}$ at $2500 \mathrm{~g}$, dissolved in distilled water, and freeze-dried. Ash and proteins were corrected.

\subsection{Proteins}

Proteins content was estimated by elemental analysis using a LECO CHNS-932 analyzer (St. Joseph, MI), and applying the factor 6.25 to convert total nitrogen into protein content. Analyses were made in triplicate.

\subsection{Ash}

Ash was determined on freeze-dried material, which was reduced to white ashes in an oven at $450^{\circ} \mathrm{C}$ overnight. Analyses were made in triplicate.

\subsection{Ascorbic Acid}

Vitamin C (L-ascorbic acid) was determined by HPLC [21]. Briefly, asparagus lyophilized samples (10 mg) were homogenized with $20 \mathrm{~mL}$ of $3 \%(\mathrm{w} / \mathrm{v})$ citric acid, and centrifuged at $20000 \mathrm{rpm}$ at $4^{\circ} \mathrm{C}$. The resulting pellet was re-extracted with $20 \mathrm{~mL}$ of citric acid solution and then centrifuged. Both supernatants were collected and taken to a final volume of $50 \mathrm{~mL}$. An aliquot of $1 \mathrm{~mL}$ was stored at $-20{ }^{\circ} \mathrm{C}$ until analysis. Samples were analyzed by HPLC using an $\mathrm{NH}_{2}$-Spherisorb (15 x 0.46-cm, 5- $\mu \mathrm{m}$ ) column (Teknokroma, Barcelona, Spain) and 100mM NaH $\mathrm{mO}_{4}$, $\mathrm{pH}=6.5$ buffer solution as mobile phase at a flow rate of $1 \mathrm{~mL} / \mathrm{min}$. Detection was performed spectrophotometrically at $260 \mathrm{~nm}$. Quantitation was achieved by constructing a calibration curve with ascorbic acid standard solutions. HPLC analyses were carried out using a Jasco-LC-Net II ADC liquid chromatograph system equipped with a diode array detector (DAD).

\subsection{Flavonoids}

Phenolic compounds, mainly flavonoids, were extracted as follow. Each sample (in duplicate), consisting on 2.5 g lyophilized material, was extracted with $100 \mathrm{~mL}$ $80 \%$ ethanol (EtOH). The samples were blended in an Ultraturrax (Ultra-Turrax T25, Janke \& Kunkel/IKA Labortechnik) at maximum speed for $1 \mathrm{~min}$ and then filtered through filter paper. Ethanolic extracts were stored at $-20^{\circ} \mathrm{C}$ until analysis by HPLC.

Analyses of flavonoids were carried out using a Jasco-LC-Net II ADC liquid chromatograph system equipped with a diode array detector (DAD). Flavonoid compounds were separated by using a MEDITERRANEA $\mathrm{SEA}_{18}$ reverse-phase analytical column (25 cm length $\mathrm{x}$ $4.6 \mu \mathrm{m}$ i.d., $5 \mu \mathrm{m}$ particle size; Teknokroma, Barcelona, Spain). The gradient profile for the separation of flavonoids was formed using solvent A (water with 1\% formic acid) and solvent B (acetonitrile with $1 \%$ formic acid) in the following program: the proportion of $\mathrm{B}$ was increased from $0 \%$ B to $20 \%$ B for the first $20 \mathrm{~min}$, then to $21 \%$ B over the next $8 \mathrm{~min}$, maintained at $21 \%$ B for 2 min, then to $30 \% \mathrm{~B}$ over the next $10 \mathrm{~min}$, and to $100 \%$ over the next $5 \mathrm{~min}$, maintained at $100 \%$ B for 5 min and finally returned to the initial conditions over the next 5 min. The flow rate was $1 \mathrm{~mL} / \mathrm{min}$ and the column temperature was $30^{\circ} \mathrm{C}$. Spectra from all peaks were recorded in the 200-600 $\mathrm{nm}$ range and the chromatograms were acquired at $360 \mathrm{~nm}$ for flavonoid glycosides and 370 $\mathrm{nm}$ for their aglycones [22].

\subsection{Hydroxycinnamic Acids}

Wall bound hydroxycinnamic acids were extracted and quantified as previously reported [15]. Briefly, samples (in duplicate) were treated with $2 \mathrm{M} \mathrm{NaOH}$ for $24 \mathrm{~h}$, at room temperature, under nitrogen in darkness. The suspension was filtered through glass fibre paper, and trans-cinnamic acid was added to the filtrate as internal standard (IS); the solutions were acidified to $\mathrm{pH}<2$ with concentrated $\mathrm{HCl}$ and then extracted three times with ethyl acetate (3 volumes). The phenolic ethyl acetate extracts were evaporated to dryness under a steam of nitrogen, and then the samples were dissolved in $200 \mu \mathrm{l}$ of $50 \%(\mathrm{v} / \mathrm{v})$ aqueous methanol prior to analysis by HPLC. The individual compounds were detected and quantified by HPLC, by using a SYNERGI $4 \mu$ HYDRO- RP80A reverse phase column (25 cm x $4.6 \mathrm{~mm}$ i.d., $4 \mu \mathrm{m}$; Phenomenex, Macclesfield, Cheshire, UK) with gradient elution employing progressively increasing methanol-acetonitrile levels in $2 \mathrm{~mL} / \mathrm{L}$ acetic acid. The gradient profile for the separation of wall bound phenolic monomers and dimers was formed using solvent A $(10 \% \quad(\mathrm{v} / \mathrm{v})$ aqueous acetonitrile plus $2 \mathrm{~mL} / \mathrm{L}$ acetic acid) and solvent B (40\% methanol, $40 \%$ acetonitrile, $20 \%$ water, plus $2 \mathrm{~mL} / \mathrm{L}$ acetic acid) in the following program: initially A 90\%, B $10 \%$; linear gradient over $17 \mathrm{~min}$ to A $57.5 \%$, B $42.5 \%$; held isocratically at A 57.5\%, B 42.5\% for further $6 \mathrm{~min}$; linear gradient over $17 \mathrm{~min}$ to B 100\%; linear gradient over 5 min to A $90 \%$, B 10\%; held isocratically at A 90\%, B $10 \%$ for further $5 \mathrm{~min}$. The flow rate was maintained at $1 \mathrm{ml} / \mathrm{min}$. Peak identification was made by using a Jasco-LC-Net II ADC liquid chromatograph system equipped with DAD and automated injector (20 $\mu \mathrm{l}$-loop). Quantitation was by integration of peak-areas at $280 \mathrm{~nm}$, with reference to calibrations made using known amounts of pure compounds.

\subsection{Antioxidant Capacity}

Total antioxidant activity was evaluated as previously described [16]. Between 3 and $20 \mathrm{mg}$ lyophilized material was transferred to an Eppendorf tube and the reaction was started by adding $1 \mathrm{~mL}$ of the $\mathrm{DPPH}^{*}$ reagent (3.8 mg/50 mL methanol). After $30 \mathrm{~min}$ of continuous 
stirring, samples were centrifuged and the absorbance of the clear supernatants were measured (in triplicate) at $480 \mathrm{~nm}$. Antioxidant activity was expressed as millimols of Trolox equivalent antioxidant capacity (TEAC) per kilogram of sample by means of a dose-response curve for Trolox.

\subsection{Statistical Analysis}

Results were expressed as mean values \pm standard deviations. To assess for differences in the composition and functional characteristics between the different asparagus samples, a multiple sample comparison was performed using the Statgraphics Plus program version 2.1. Multivariate analysis of variance (ANOVA), followed by Duncan's multiple comparison test, was performed to contrast the groups. The level of significance used was $\mathrm{P}<0.05$.

\section{Results}

\subsection{General}

We have studied 11 different samples of white asparagus and 10 of green ones that include the most representative brands and commercial presentations (tin or glass containers) available in Spanish markets. The samples of white and green asparagus have been labelled as $\mathrm{W} 1$ to $\mathrm{W} 11$ and G1 to G10 respectively in order to preserve the identity of different brands analyzed. Commercial characteristics of canned white and green asparagus, including origin of the samples, packing type and spears size are presented in Table 1 and Table 2 respectively.

Asparagus may be classified as very small, small, medium, large, or extra-large depending upon the diameter of the spears, but there is no general consensus on the classification parameters. The categories of canned white asparagus available in local markets are: medium, large, very large and extra-large, but we have found some samples labelled as large having greater size than other ones labelled as very large. On the other hand, samples labelled as medium and large had the same size. This lack of consensus about canned asparagus classification did not affect the results and discussion of the present work as we have found that there are no significant differences of nutritional and functional composition depending on spear size. For comparative purposes, we classified white asparagus in medium (diameter $<10 \mathrm{~mm}$ ), large $(10-15 \mathrm{~mm})$ and extra-large $(>15 \mathrm{~mm})$; and green asparagus in small (diameter $<8 \mathrm{~mm})$, medium $(8-10 \mathrm{~mm})$ and large $(>10$ $\mathrm{mm})$. Spear length varied between $14-16 \mathrm{~cm}$ for white asparagus and 11-15 cm for the green ones [23].

Spain has traditionally been an important producer of both white and green asparagus, but the importation of asparagus from China and Peru has gradually increased in our country during the last two decades, these main producers representing a tough competition for the national asparagus [24]. However, our local product has managed to maintain and even increase its demand in the last two years, thanks to its excellent and differential sensorial and nutritional characteristics, highly appreciated by the consumer. Hence, as it can be observed in Table 1 and Table 2, almost $50 \%$ of the samples in our supermarkets are of national origin.

In Spain, there are two important areas producing white and green asparagus that combine a large part of their production under the protected geographical indications (PGI) white asparagus of Navarra and triguero asparagus of Huétor-Tájar (Granada). There are also several companies producing organic asparagus (Table 1 and Table 2). Results showed in the tables are the mean of two replicates. Means within a column bearing the same letter are not significantly different at $5 \%$ level as determined by the Duncan multiple range test.

Table 1. Commercial Characteristics of Canned White Asparagus

\begin{tabular}{ccccc}
\hline & Origin & $\begin{array}{c}\text { Diameter } \\
(\mathrm{mm})\end{array}$ & $\begin{array}{c}\text { Length } \\
(\mathrm{cm})\end{array}$ & $\begin{array}{c}\text { Spear Weight } \\
(\mathrm{g})\end{array}$ \\
\hline W1 & China & $9.99 \pm 0.64 \mathrm{a}$ & 15 & $23.38 \pm 0.84 \mathrm{ab}$ \\
W2 & China & $17.05 \pm 1.25 \mathrm{c}$ & 14 & $43.30 \pm 0.97 \mathrm{e}$ \\
W3 & Navarra-ECO (Spain) & $10.04 \pm 1.03 \mathrm{a}$ & 15.5 & $23.56 \pm 0.16 \mathrm{ab}$ \\
W4 & Peru & $20.45 \pm 0.92 \mathrm{~d}$ & 13.5 & $42.38 \pm 0.01 \mathrm{e}$ \\
W5 & China & $10.31 \pm 1.05 \mathrm{a}$ & 16 & $22.94 \pm 0.27 \mathrm{ab}$ \\
W6 & Peru & $15.03 \pm 2.71 \mathrm{~b}$ & 14.5 & $25.47 \pm 0.35 \mathrm{~b}$ \\
W7 & Peru & $20.01 \pm 2.91 \mathrm{~d}$ & 14.5 & $44.17 \pm 1.17 \mathrm{e}$ \\
W8 & Navarra-PGI (Spain) & $17.03 \pm 2.03 \mathrm{c}$ & 14.5 & $29.57 \pm 1.89 \mathrm{c}$ \\
W9 & Navarra-ECO (Spain) & $15.06 \pm 1.81 \mathrm{~b}$ & 15 & $35.60 \pm 2.19 \mathrm{~d}$ \\
W10 & Navarra-PGI (Spain) & $15.04 \pm 2.37 \mathrm{~b}$ & 15 & $24.69 \pm 2.37 \mathrm{~b}$ \\
W11 & Navarra-PGI (Spain) & $14.01 \pm 2.44 \mathrm{~b}$ & 15 & $20.91 \pm 2.72 \mathrm{a}$ \\
\hline
\end{tabular}

Table 2. Commercial Characteristics of Canned Green Asparagus

\begin{tabular}{ccccc}
\hline & Origin & Diameter (mm) & $\begin{array}{c}\text { Length } \\
(\mathrm{cm})\end{array}$ & $\begin{array}{c}\text { Spear Weight } \\
(\mathrm{g})\end{array}$ \\
\hline G1 & Peru & $7.50 \pm 1.26 \mathrm{~b}$ & 14 & $4.71 \pm 0.39 \mathrm{~b}$ \\
G2 & Peru & $15.04 \pm 1.64 \mathrm{~d}$ & 15 & $22.32 \pm 1.68 \mathrm{~g}$ \\
G3 & Navarra-ECO (Spain) & $10.12 \pm 1.00 \mathrm{c}$ & 15 & $8.01 \pm 0.04 \mathrm{c}$ \\
G4 & Granada (Spain) & $15.00 \pm 1.56 \mathrm{~d}$ & 14 & $19.26 \pm 0.56 \mathrm{f}$ \\
G5 & China & $10.41 \pm 1.07 \mathrm{c}$ & 10 & $7.87 \pm 0.10 \mathrm{c}$ \\
G6 & Peru & $10.07 \pm 0.91 \mathrm{c}$ & 15 & $9.94 \pm 0.32 \mathrm{~d}$ \\
G7 & Peru & $10.37 \pm 0.96 \mathrm{c}$ & 15 & $11.40 \pm 0.02 \mathrm{e}$ \\
G8 & Peru & $7.58 \pm 0.79 \mathrm{~b}$ & 11 & $5.61 \pm 0.14 \mathrm{~b}$ \\
G9 & Granada-PGI (Spain) & $10.03 \pm 1.10 \mathrm{c}$ & 11.5 & $7.47 \pm 0.18 \mathrm{c}$ \\
G10 & Granada-PGI (Spain) & $5.03 \pm 0.74 \mathrm{a}$ & 11 & $2.89 \pm 0.06 \mathrm{a}$ \\
\hline
\end{tabular}

\subsection{Chemical Characterization}

We have analyzed the chemical profile of the main components that contribute to determine asparagus nutritional quality, and that may also influence the sensorial attributes and the functional properties of this appreciated vegetable. Its composition is usually associated with a low caloric intake and high fiber content, which is of great interest in the food-health field.

Table 3 and Table 4 summarize the chemical composition of white and green asparagus, including macronutrients, dietary fiber, micronutrients and phytochemicals. Values of antioxidant activity, expressed as millimoles of Trolox equivalent antioxidant capacity (TEAC) per kilogram of sample, are shown together the chemical composition.

As it can be observed in the Table 3 and Table 4 asparagus edible portions mainly contain water that represents $93-96 \%$ of the total weight and its content is slightly greater in white than in green spears. The content and composition of dietary fibre, whose interesting physico-chemical and functional properties are well 
established [25,26] also contribute to consider asparagus as a very healthy and nutritious vegetable.

\subsubsection{Proteins}

They were the most abundant macronutrients in asparagus spears and its content was almost twice higher in green (2.26\% average value) than in white ones $(1.33 \%)$. It is remarkable that samples from Navarra presented the highest contents of proteins, whereas the three samples from Peru (W4, W6 and W7) showed the lowest protein values of the second group. The protein contents of the green samples were quite distinct among all the investigated samples and varied between 1.78 and 2.96\%, with samples G-9 and G-10 being those with the highest protein content.

\subsubsection{Soluble Sugars}

These macronutrients were also found in white and green asparagus, while neither of them contained lipids. Sugars were the only components whose content was higher in white (1.20\% average value) than in green spears, ( $0.71 \%$ average value). Most white samples contained about $1.00 \%$ sugars, with the exception of those samples that proceed from Peru (W4, W6 and W7) that contained significant higher amounts (nearly $1.50 \%$ ) as it can be observed in Table 3 . The content of soluble sugars from all the green samples was very similar as it can be observed in Table 4.

\subsubsection{Total Dietary Fiber}

Fiber constitutes about $1 \%$ of white spears and $1.5 \%$ of the green ones which is a significant percentage taking in account the high moisture values. The fiber content was very similar in all the samples of white asparagus, and only the values of W-5 (1.34\%) and W-11 (1.64\%) were slightly higher than the average value (1.16\%). In general, green asparagus contained more total fibre (average value 1.39\%) than the white ones and there were two samples, G-9 (1.81\%) and G-10 (1.76\%) with marked higher fiber contents than the others.

\subsubsection{Minerals}

They were quantified as ash content, constituted about $1.00 \%$ of both white and green spears and there were just slight differences among samples.

Table 3. Chemical Composition of Canned White Asparagus

\begin{tabular}{|c|c|c|c|c|c|c|c|c|}
\hline & $\begin{array}{l}\text { Moisture } \\
\text { (g/100 g) }\end{array}$ & $\begin{array}{l}\text { Protein } \\
\text { (g/100 g) }\end{array}$ & $\begin{array}{l}\text { Soluble sugar } \\
\text { (g/100 g) }\end{array}$ & $\begin{array}{l}\text { Dietary fibre } \\
\text { (g/100 g) }\end{array}$ & $\begin{array}{c}\text { Ash } \\
\text { (g/100 g) }\end{array}$ & $\begin{array}{l}\text { Ascorbic acid } \\
\text { (mg/100 g) }\end{array}$ & $\begin{array}{c}\text { Esterified } \\
\text { phenols } \\
\text { (mg/100 g) }\end{array}$ & $\begin{array}{c}\text { Antiradical } \\
\text { activity (mmol } \\
\text { Trolox/Kg ) } \\
\end{array}$ \\
\hline W1 & $95.39 \pm 0.33 \mathrm{~b}$ & $1.16 \pm 0.01 \mathrm{c}$ & $1.22 \pm 0.07$ bcd & $1.02 \pm 0.00 \mathrm{a}$ & $0.94 \pm 0.01 \mathrm{e}$ & $9.96 \pm 1.03 \mathrm{f}$ & $0.098 \pm 0.001 \mathrm{a}$ & $52.79 \pm 7.07$ e \\
\hline W2 & $95.64 \pm 0.37 \mathrm{~b}$ & $1.17 \pm 0.01 \mathrm{c}$ & $1.18 \pm 0.01 \mathrm{abc}$ & $1.14 \pm 0.01$ bc & $0.90 \pm 0.00 \mathrm{~d}$ & $10.80 \pm 1.40 \mathrm{f}$ & $0.209 \pm 0.067 \mathrm{c}$ & $37.27 \pm 3.06 \mathrm{ab}$ \\
\hline W3 & $94.36 \pm 0.04 \mathrm{ab}$ & $1.50 \pm 0.00 \mathrm{f}$ & $1.03 \pm 0.12 \mathrm{ab}$ & $1.06 \pm 0.02 \mathrm{a}$ & $1.16 \pm 0.01 \mathrm{~h}$ & $7.98 \pm 1.11$ abcd & n.d. & $39.66 \pm 1.68$ bc \\
\hline W4 & $95.46 \pm 0.04 \mathrm{~b}$ & $0.88 \pm 0.00 \mathrm{a}$ & $1.46 \pm 0.01 \mathrm{e}$ & $1.05 \pm 0.04 \mathrm{a}$ & $0.65 \pm 0.01 \mathrm{a}$ & $9.44 \pm 0.55$ ef & $0.160 \pm 0.011 \mathrm{~b}$ & $32.11 \pm 0.54 \mathrm{a}$ \\
\hline W5 & $93.81 \pm 1.34 \mathrm{ab}$ & $1.59 \pm 0.00 \mathrm{~g}$ & $1.25 \pm 0.02 \mathrm{~cd}$ & $1.34 \pm 0.00 \mathrm{~d}$ & $1.06 \pm 0.00 \mathrm{~g}$ & $8.97 \pm 0.58$ cdef & $0.235 \pm 0.003 \mathrm{c}$ & $74.31 \pm 0.35 \mathrm{f}$ \\
\hline W6 & $95.09 \pm 1.54 \mathrm{~b}$ & $1.06 \pm 0.03 \mathrm{~b}$ & $1.41 \pm 0.05$ de & $1.08 \pm 0.06 \mathrm{ab}$ & $0.76 \pm 0.01 \mathrm{~b}$ & $8.05 \pm 0.35$ bcde & $0.204 \pm 0.010$ bc & $42.91 \pm 0.17$ bcd \\
\hline W7 & $95.11 \pm 0.39 \mathrm{~b}$ & $1.02 \pm 0.02 \mathrm{~b}$ & $1.48 \pm 0.23 \mathrm{e}$ & $1.04 \pm 0.00 \mathrm{a}$ & $0.82 \pm 0.00 \mathrm{c}$ & $8.69 \pm 1.02$ bcdef & n.d. & $37.51 \pm 1.48 \mathrm{ab}$ \\
\hline W8 & $95.30 \pm 0.43 \mathrm{~b}$ & $1.34 \pm 0.04 \mathrm{e}$ & $1.07 \pm 0.07 \mathrm{abc}$ & $1.07 \pm 0.02 \mathrm{a}$ & $0.91 \pm 0.02 \mathrm{~d}$ & $7.44 \pm 0.10 \mathrm{ab}$ & n.d. & $45.39 \pm 1.21 \mathrm{~cd}$ \\
\hline W9 & $94.68 \pm 0.52 a b$ & $1.67 \pm 0.03 \mathrm{~h}$ & $1.02 \pm 0.09 \mathrm{a}$ & $1.20 \pm 0.01 \mathrm{c}$ & $1.04 \pm 0.01 \mathrm{fg}$ & $7.80 \pm 1.23 \mathrm{abc}$ & $0.225 \pm 0.010 \mathrm{c}$ & $47.59 \pm 0.18$ de \\
\hline W10 & $94.97 \pm 0.67 \mathrm{~b}$ & $1.26 \pm 0.01 \mathrm{~d}$ & $1.11 \pm 1.11 \mathrm{abc}$ & $1.06 \pm 0.03 \mathrm{a}$ & $1.03 \pm 0.01 \mathrm{f}$ & $6.41 \pm 1.72 \mathrm{a}$ & n.d. & $38.94 \pm 3.70 \mathrm{~b}$ \\
\hline
\end{tabular}

Means within a column bearing the same letter are not significantly different at $5 \%$ level as determined by the Duncan multiple range test.

Table 4. Chemical Composition of Canned Green Asparagus

\begin{tabular}{cccccccccc}
\hline & $\begin{array}{c}\text { Moisture } \\
(\mathrm{g} / 100 \mathrm{~g})\end{array}$ & $\begin{array}{c}\text { Protein } \\
(\mathrm{g} / 100 \mathrm{~g})\end{array}$ & $\begin{array}{c}\text { Soluble sugar } \\
(\mathrm{g} / 100 \mathrm{~g})\end{array}$ & $\begin{array}{c}\text { Dietary fibre } \\
(\mathrm{g} / 100 \mathrm{~g})\end{array}$ & $\begin{array}{c}\text { Ash } \\
(\mathrm{g} / 100 \mathrm{~g})\end{array}$ & $\begin{array}{c}\text { Flavonoids } \\
(\mathrm{mg} / 100 \mathrm{~g})\end{array}$ & $\begin{array}{c}\text { Ascorbic acid } \\
(\mathrm{mg} / 100 \mathrm{~g})\end{array}$ & $\begin{array}{c}\text { Esterified phenols } \\
(\mathrm{mg} / 100 \mathrm{~g})\end{array}$ & $\begin{array}{c}\text { Antiradical } \\
\text { activity }(\mathrm{mmol} \\
\mathrm{Trolox} / \mathrm{Kg})\end{array}$ \\
\hline G1 & $94.19 \pm 0.72 \mathrm{bc}$ & $2.31 \pm 0.09 \mathrm{e}$ & $0.79 \pm 0.01 \mathrm{bc}$ & $1.42 \pm 0.01 \mathrm{e}$ & $0.89 \pm 0.0 \mathrm{bc}$ & $22.21 \pm 1.64 \mathrm{c}$ & $10.31 \pm 0.31 \mathrm{cde}$ & $0.390 \pm 0.028 \mathrm{ab}$ & $145.84 \pm 0.44 \mathrm{~d}$ \\
$\mathrm{G} 2$ & $94.06 \pm 0.32 \mathrm{bc}$ & $1.94 \pm 0.06 \mathrm{~b}$ & $0.76 \pm 0.14 \mathrm{bc}$ & $1.33 \pm 0.00 \mathrm{~cd}$ & $0.91 \pm 0.01 \mathrm{c}$ & $15.96 \pm 0.43 \mathrm{a}$ & $10.04 \pm 0.69 \mathrm{~cd}$ & $0.489 \pm 0.040 \mathrm{c}$ & $109.11 \pm 6.28 \mathrm{~b}$ \\
$\mathrm{G} 3$ & $94.40 \pm 0.52 \mathrm{bc}$ & $2.08 \pm 0.01 \mathrm{~cd}$ & $0.62 \pm 0.01 \mathrm{ab}$ & $1.22 \pm 0.04 \mathrm{ab}$ & $0.98 \pm 0.01 \mathrm{~d}$ & $22.59 \pm 0.53 \mathrm{c}$ & $7.54 \pm 0.37 \mathrm{a}$ & $0.453 \pm 0.055 \mathrm{bc}$ & $108.85 \pm 7.25 \mathrm{~b}$ \\
$\mathrm{G} 4$ & $93.61 \pm 0.40 \mathrm{ab}$ & $2.02 \pm 0.05 \mathrm{bc}$ & $0.79 \pm 0.15 \mathrm{bc}$ & $1.38 \pm 0.00 \mathrm{de}$ & $1.37 \pm 0.01 \mathrm{f}$ & $32.12 \pm 0.78 \mathrm{~d}$ & $8.45 \pm 0.58 \mathrm{ab}$ & $0.416 \pm 0.019 \mathrm{abc}$ & $108.43 \pm 3.86 \mathrm{~b}$ \\
G5 & $93.91 \pm 0.14 \mathrm{bc}$ & $2.54 \pm 0.03 \mathrm{f}$ & $0.47 \pm 0.13 \mathrm{a}$ & $1.26 \pm 0.00 \mathrm{bc}$ & $0.84 \pm 0.03 \mathrm{a}$ & $22.01 \pm 0.97 \mathrm{c}$ & $10.63 \pm 0.64 \mathrm{def}$ & $0.493 \pm 0.051 \mathrm{c}$ & $135.43 \pm 6.17 \mathrm{~d}$ \\
G6 & $94.25 \pm 0.10 \mathrm{bc}$ & $1.78 \pm 0.03 \mathrm{a}$ & $0.87 \pm 0.04 \mathrm{c}$ & $1.35 \pm 0.02 \mathrm{de}$ & $0.83 \pm 0.00 \mathrm{a}$ & $19.63 \pm 0.92 \mathrm{~b}$ & $12.17 \pm 0.09 \mathrm{~g}$ & $0.584 \pm 0.014 \mathrm{~d}$ & $88.92 \pm 2.16 \mathrm{a}$ \\
G7 & $94.24 \pm 0.44 \mathrm{bc}$ & $2.05 \pm 0.02 \mathrm{~cd}$ & $0.87 \pm 0.09 \mathrm{c}$ & $1.19 \pm 0.00 \mathrm{ab}$ & $0.85 \pm 0.00 \mathrm{ab}$ & $22.22 \pm 0.54 \mathrm{c}$ & $9.29 \pm 0.14 \mathrm{bc}$ & $0.353 \pm 0.011 \mathrm{a}$ & $121.79 \pm 9.18 \mathrm{bc}$ \\
G8 & $94.85 \pm 0.65 \mathrm{c}$ & $2.14 \pm 0.02 \mathrm{~d}$ & $0.66 \pm 0.01 \mathrm{ab}$ & $1.15 \pm 0.07 \mathrm{a}$ & $0.82 \pm 0.02 \mathrm{a}$ & $18.80 \pm 0.51 \mathrm{~b}$ & $11.44 \pm 0.47 \mathrm{efg}$ & $0.643 \pm 0.033 \mathrm{~d}$ & $86.56 \pm 4.43 \mathrm{a}$ \\
G9 & $92.53 \pm 0.74 \mathrm{a}$ & $2.96 \pm 0.04 \mathrm{~h}$ & $0.66 \pm 0.02 \mathrm{ab}$ & $1.81 \pm 0.05 \mathrm{f}$ & $1.37 \pm 0.01 \mathrm{f}$ & $36.98 \pm 0.88 \mathrm{e}$ & $11.58 \pm 1.33 \mathrm{fg}$ & $0.452 \pm 0.001 \mathrm{bc}$ & $140.19 \pm 10.07 \mathrm{~d}$ \\
G10 & $92.75 \pm 0.63 \mathrm{a}$ & $2.83 \pm 0.03 \mathrm{~g}$ & $0.61 \pm 0.09 \mathrm{ab}$ & $1.76 \pm 0.05 \mathrm{f}$ & $1.33 \pm 0.01 \mathrm{e}$ & $45.58 \pm 0.30 \mathrm{f}$ & $7.74 \pm 1.11 \mathrm{a}$ & $0.422 \pm 0.047 \mathrm{abc}$ & $134.65 \pm 2.38 \mathrm{~cd}$ \\
\hline
\end{tabular}

Means within a column bearing the same letter are not significantly different at $5 \%$ level as determined by the Duncan multiple range test. 


\subsubsection{Flavonoids}

These phenolic compounds were no detected in any of the white asparagus samples, whereas they were found in significant amounts in all the green ones. The total content and the composition of flavonoids showed great differences among the green samples. As it can be observed in Table 4, samples G4, G9 and G10 that proceed from Granada, Spain, contained up to 2 fold than G2 that comes from Peru.

\subsubsection{Ascorbic Acid}

The content of ascorbic acid ranged from 6.41 to 10.80 $\mathrm{mg} / 100 \mathrm{~g}$ fresh weight, and a high variability was found among the samples of white asparagus analyzed (Table 3). The green samples contained, in general, similar amounts of ascorbic acid than the white ones, although in three of the samples values were higher than those of the rest and above the highest values in white asparagus (Table 4).

\subsubsection{Esterified Phenolics}

Phenolic compounds linked to the cell walls included several hydroxycinnamic acids, which were also much more abundant in green than in white samples, and, in general they were quantified in very low amounts. Although these esterified phenolics are present in low proportion, they play an important role within the cell wall and confer an additional value to asparagus fibre.

\subsection{Factors Influencing Nutritional and Functional Quality of Canned Asparagus}

\subsubsection{Asparagus Processing and Their Subsequent Storage}

These procedures caused decreases in the antioxidant capacity that are related to the losses of main asparagus antioxidants, phenols and ascorbic acid. It has been reported that polyphenols and vitamin $\mathrm{C}$ decrease in percentages near $50 \%$ after canning or boiling by solubilization to treatment liquids [27]. In the same way, it has been found that the content of ascorbic acid, main responsible of antioxidant capacity in white asparagus, decreased between 40 and $60 \%$ depending on asparagus variety [28]. We investigated the influence of industrial processing on three distinct samples of green asparagus from Huetor-Tájar in two subsequent seasons, 2013 and
2014. The samples investigated consisted on: spears from the Huétor-Tájar population variety (Triguero-HT), one of the most cultivated commercial hybrids of green asparagus (Grande) and a new variety of triguero asparagus that has been developed from native lines of Huétor-Tájar (HT-801). Analyses of the nutritional and phytochemical composition of fresh and cooked spears from the three samples are summarized in Table 5.

The results revealed that industrial process did not affect to a great extension the nutritional value of green asparagus, as protein, free aminoacids, soluble sugar and dietary fibre did not change or just slightly decreased after processing. However, bioactive compounds related to functional quality of the spears, such as phenolics and ascorbic acid, significantly decreased. Flavonoid contents were 57.84, 76.05 and $72.48 \mathrm{mg} / 100 \mathrm{~g}$ for fresh samples (Triguero-HT, Grande and HT-801 respectively) and 47.67, 57.36 and $56.12 \mathrm{mg} / 100 \mathrm{~g}$ for the processed ones, which represented 27\%, 24\% and 23\% loss respectively. Ascorbic acid content was even more affected: the values for fresh samples were 45.55, 33.55 and $44.94 \mathrm{mg} / 100 \mathrm{~g}$, while those decreased to 21.22, 22.95 and $25.01 \mathrm{mg} / 100 \mathrm{~g}$ in the processed samples (Triguero-HT, Grande and HT801 respectively), which meant 53\%, 33\% and 44\% loss respectively. It is noteworthy that samples G9 and G10 investigated in the present work are from the same type and origin than those above described and their contents of flavonoids (36.98 mg/100g and $45.58 \mathrm{mg} / 100 \mathrm{~g}$ ) and ascorbic acid (11.58 mg/100g and $7.74 \mathrm{mg} / 100 \mathrm{~g}$ ) are also comparable but slightly lower (Table 4). There is a significant variability among the data from the different samples of Triguero-HT asparagus analyzed, which can be explained by the fact that they are not commercial cultivars, but a population variety that includes genotypes from different species and a new variety developed by the local farmers from that wide population. On the other hand, if well the samples that we analyzed for two consecutive seasons and the samples G9 and G10 from the market study are from the same origin, there are several factors, including season year, harvest date, storage postprocessing and so on, which have not been possible to standardize; and it is well stablished that they can affect the composition of the final product. Nevertheless, it can be concluded that these samples from triguero asparagus are a very good source of antioxidant compounds, being at the position among all the commercial presentations.

Table 5. Chemical Composition of Fresh and Canned Green Asparagus from Huétor-Tájar

\begin{tabular}{|c|c|c|c|c|c|c|c|c|}
\hline & $\begin{array}{l}\text { Moisture } \\
\text { (g/100 g) }\end{array}$ & $\begin{array}{l}\text { Protein } \\
\text { (g/100 g) }\end{array}$ & $\begin{array}{c}\text { Soluble sugar } \\
(\mathrm{g} / 100 \mathrm{~g})\end{array}$ & $\begin{array}{l}\text { Dietary fibre } \\
(\mathrm{g} / 100 \mathrm{~g})\end{array}$ & $\begin{array}{c}\text { Ash } \\
\text { (g/100 g) }\end{array}$ & $\begin{array}{l}\text { Flavonoids } \\
\text { (mg/100 g) }\end{array}$ & $\begin{array}{c}\text { Ascorbic acid } \\
(\mathrm{mg} / 100 \mathrm{~g})\end{array}$ & $\begin{array}{c}\text { Esterified phenols } \\
(\mathrm{mg} / 100 \mathrm{~g})\end{array}$ \\
\hline \multicolumn{9}{|l|}{$\underline{\text { Fresh }}$} \\
\hline Triguero-HT & $91.59 \pm 0.17$ abc & $3.39 \pm 0.04 \mathrm{~d}$ & $1.96 \pm 0.05 \mathrm{c}$ & $1.74 \pm 0.014 \mathrm{~b}$ & $0.84 \pm 0.057 \mathrm{a}$ & $57.84 \pm 3.48 \mathrm{~b}$ & $45.55 \pm 2.76 \mathrm{c}$ & $2.53 \pm 0.09 \mathrm{e}$ \\
\hline Grande & $92.20 \pm 0.64$ bcd & $2.96 \pm 0.14$ bc & $2.57 \pm 0.03 \mathrm{e}$ & $1.80 \pm 0.102 \mathrm{~b}$ & $0.87 \pm 0.001 \mathrm{a}$ & $76.05 \pm 3.18 \mathrm{c}$ & $33.55 \pm 4.13 \mathrm{~b}$ & $1.96 \pm 0.05 \mathrm{c}$ \\
\hline HT-801 & $91.15 \pm 0.28 \mathrm{ab}$ & $3.43 \pm 0.09 \mathrm{~d}$ & $2.11 \pm 0.04 \mathrm{~d}$ & $2.14 \pm 0.014 \mathrm{c}$ & $1.01 \pm 0.007 \mathrm{~b}$ & $72.48 \pm 0.09 \mathrm{c}$ & $44.94 \pm 2.91 \mathrm{c}$ & $2.13 \pm 0.07 \mathrm{~d}$ \\
\hline \multicolumn{9}{|l|}{$\underline{\text { Canned }}$} \\
\hline Triguero-HT & $92.30 \pm 0.07 \mathrm{~cd}$ & $2.83 \pm 0.01 \mathrm{~b}$ & $1.53 \pm 0.04 \mathrm{~b}$ & $1.73 \pm 0.029 \mathrm{~b}$ & $1.52 \pm 0.014 \mathrm{c}$ & $47.67 \pm 5.34 \mathrm{a}$ & $21.22 \pm 0.28 \mathrm{a}$ & $0.42 \pm 0.05 \mathrm{~b}$ \\
\hline Grande & $93.01 \pm 0.22 \mathrm{~d}$ & $1.99 \pm 0.08 \mathrm{a}$ & $1.98 \pm 0.08 \mathrm{c}$ & $1.51 \pm 0.022 \mathrm{a}$ & $1.58 \pm 0.001 \mathrm{c}$ & $57.36 \pm 1.53 \mathrm{~b}$ & $22.95 \pm 0.16 \mathrm{a}$ & $0.25 \pm 0.01 \mathrm{a}$ \\
\hline НТ-801 & $91.07 \pm 0.79 \mathrm{a}$ & $3.12 \pm 0.07$ c & $1.38 \pm 0.05 \mathrm{a}$ & $2.09 \pm 0.007 \mathrm{c}$ & $1.85 \pm 0.022 \mathrm{~d}$ & $56.12 \pm 0.58 \mathrm{~b}$ & $25.01 \pm 0.02 \mathrm{a}$ & $0.28 \pm 0.01 \mathrm{a}$ \\
\hline
\end{tabular}

Means within a column bearing the same letter are not significantly different at $5 \%$ level as determined by the Duncan multiple range test. 
In the last years, there is an increasing concern about preserve not only the nutrients, but also the bioactive components, mainly antioxidants, during the storage and processing of plant food. In that way, the optimization of industrial processing and the development of new methods of preservation carried out during the last years have managed to maintain to a great extension the antioxidant properties in canned asparagus. Asparagus, which has been previously reported as one of the richest vegetables with a view to total quantity and quality of antioxidants $[4,5]$, it is also one of the plant-food that least loss sufferers during industrial processing and subsequent conservation once canned. Hence, its processing resulted in $1.2 \%$ loss of total antioxidant capacity, and during the subsequent storage (18 months) it only decreased by $0.7 \%$ [19]. Total antioxidant capacity reported by the authors of those studies is very similar to the average value from the 10 green commercial samples analyzed in this work.

We have also compared the chemical composition of both white and green asparagus (Table 3 and Table 4) with data reported by USDA in their National Nutrient Database for Standard Reference. This Database contains information provided by two manufacturers of white asparagus, whose brands correspond to two of the samples investigated in the present work. The reported contents of protein (0.97 and $0.80 \mathrm{~g} / 100 \mathrm{~g}$ ), soluble sugars (0.97 and $1.60 \mathrm{~g} / 100 \mathrm{~g})$ dietary fiber $(1.0$ and $1.6 \mathrm{~g} / 100 \mathrm{~g})$ and ascorbic acid (20.4 and $5.0 \mathrm{mg} / 100 \mathrm{~g})[29,30]$ were in the same range of the average values from the 11 white asparagus samples that we have analyzed (Table 6). It is remarkable the substantial variability of vitamin $\mathrm{C}$ and, into a less extension, sugars and dietary fiber contents reported by different brands of white asparagus. These findings could be explained by the specific processing conditions that are used by each asparagus manufacturer, as minor modifications on cooking time and/or temperature may cause significant differences on thermo-sensitive components, such as ascorbic acid. The data from our analyses (Table 3) are equivalent to the average values from Databases (about $9 \mathrm{mg} / 100 \mathrm{~g}$ ) and they increased to $13 \mathrm{mg} / 100 \mathrm{~g}$ when it was also quantified the ascorbic acid amount that was solubilized from the spears to the canning liquid or brine during asparagus processing. Full reports (all nutrients) of canned green asparagus are also available from USDA National Nutrient Database, differentiating between data obtained from liquid and solids samples [31] and drained solids [32]. Although there are not important differences among those samples, it is noteworthy that data reported for main components, such as proteins, dietary fiber and ascorbic acid are slightly higher in drained solids samples (2.14 g/100g, 1.6 g/100g and 18.4 $\mathrm{mg} / 100 \mathrm{~g}$ respectively) than in those samples in which have been also quantified the components that are solubilized to canning liquids from the spears $(1.80 \mathrm{~g} / 100 \mathrm{~g}$, $1.0 \mathrm{~g} / 100 \mathrm{~g}$ and $16.5 \mathrm{mg} / 100 \mathrm{~g})$, during their processing. The average composition of the 10 green asparagus samples investigated in the present work is comparable to that above described. As it can be observed in Table 6, the contents of protein, dietary fiber and ascorbic acid were $2.26 \mathrm{~g} / 100 \mathrm{~g}, 1.39 \mathrm{~g} / 100 \mathrm{~g}$ and $9.84 \mathrm{~g} / 100 \mathrm{~g}$ respectively. It is noteworthy that whereas protein and fiber contents of our samples were equivalent or even slightly greater than those found in Reference Databases, ascorbic acid quantity was significant lower. However, the average value increased to $14.36 \mathrm{mg} / 100 \mathrm{~g}$ taking into account the content of spear plus liquid processing.

In addition to ascorbic acid, flavonoids are one of the main determinants of green asparagus antioxidant activity and they are also considerably affected during processing. The percent of individual flavonoids solubilized into the brines of commercial canned green asparagus are summarized in Table 6. As it can be observed in the table, the brines contained about a third part of the total flavonoid quantities present in the cans (spear plus brine) and that solubilization affects in a similar level to each of the individual flavonoids, with some exceptions that it is noteworthy to highlight. Rutin, the main flavonoid glycoside in asparagus, was present in the brines in quantities that represent about $20-40 \%$ total flavonoid content in almost analyzed samples (G1-G8). However, those percentages are much lower in triguero asparagus amples (G9 and G10), in which the percentages of solubilized rutin were 11.41 and $8.59 \%$ respectively. This better preservation of phenolic compounds in triguero asparagus can be explained by the influence of two distinct factors: the milder conditions of cooking that use in their canning industries and the genetic and environmental factors that contribute not only to enhance phytochemical levels of fresh samples, but also to improve their stability during postharvest storage and process. These facts are better explained in next paragraph.

Table 6. Percent of Flavonoids Solubilized into the Brines of Canned Green Asparagus, expressed on Total Quantified Flavonoids (Spears plus Brines)

\begin{tabular}{ccccc}
\hline & IR-triglyc & Rutin & Nicotiflorin & Narcisin \\
\hline G1 & $36.59 \pm 0.37 \mathrm{abc}$ & $32.03 \pm 0.76 \mathrm{e}$ & $18.20 \pm 0.86 \mathrm{ab}$ & $29.89 \pm 1.93 \mathrm{ab}$ \\
G2 & $63.72 \pm 15.65 \mathrm{~d}$ & $34.98 \pm 0.14 \mathrm{f}$ & $100.00 \pm 0.00 \mathrm{c}$ & $28.75 \pm 2.20 \mathrm{ab}$ \\
G3 & $35.34 \pm 0.88 \mathrm{abc}$ & $24.09 \pm 0.03 \mathrm{~d}$ & $18.69 \pm 0.44 \mathrm{~b}$ & $34.97 \pm 5.18 \mathrm{ab}$ \\
G4 & $29.77 \pm 3.29 \mathrm{a}$ & $20.59 \pm 0.38 \mathrm{c}$ & $16.46 \pm 0.71 \mathrm{ab}$ & $32.86 \pm 1.37 \mathrm{ab}$ \\
G5 & $34.29 \pm 0.66 \mathrm{abc}$ & $30.27 \pm 0.61 \mathrm{e}$ & $16.33 \pm 0.07 \mathrm{a}$ & $22.91 \pm 3.88 \mathrm{a}$ \\
G6 & $42.40 \pm 0.89 \mathrm{c}$ & $42.02 \pm 0.78 \mathrm{~g}$ & $100.00 \pm 0.00 \mathrm{c}$ & $31.34 \pm 4.30 \mathrm{ab}$ \\
G7 & $40.10 \pm 0.18 \mathrm{c}$ & $36.56 \pm 0.61 \mathrm{f}$ & $17.88 \pm 0.64 \mathrm{ab}$ & $33.53 \pm 1.44 \mathrm{ab}$ \\
G8 & $39.27 \pm 4.02 \mathrm{bc}$ & $35.44 \pm 0.17 \mathrm{f}$ & $18.45 \pm 0.62 \mathrm{ab}$ & $38.61 \pm 1.05 \mathrm{~b}$ \\
G9 & $33.97 \pm 0.87 \mathrm{abc}$ & $11.41 \pm 0.33 \mathrm{~b}$ & $18.23 \pm 0.38 \mathrm{ab}$ & $32.46 \pm 4.56 \mathrm{ab}$ \\
G10 & $32.00 \pm 1.95 \mathrm{ab}$ & $8.59 \pm 0.02 \mathrm{a}$ & $18.16 \pm 0.41 \mathrm{ab}$ & $23.77 \pm 0.83 \mathrm{a}$ \\
\hline
\end{tabular}

\subsubsection{Genetic and Environmental Factors}

The variety, origin and cultivation conditions of the spears also affect asparagus chemical composition, as it has been reported by many authors during the last decade. Most studies have been focused on bioactive compounds, mainly antioxidants, and its potential beneficial effects on human health [7,32,34,35].

We have previously established that green asparagus have greater content of phytochemicals, mainly phenolics, and higher values of antioxidant capacity than the white ones [36,37]. These results are in consonance with those from two other Groups who investigated the influence of genetic and environmental factors on the composition of white and green spears cultivated in Japan and Greece respectively [34,39]. In addition to phenolic compounds, ascorbic acid concentration significantly determines 
asparagus antioxidant activity, mainly in white spears that contain significant lower quantities of total phenols than the green ones, as reported by Takacs-Hajos et al. (2015). The results of a trial developed in Hungary, focused in determining the antioxidant status of three different cultivars of white asparagus, indicated that ascorbic acid contents of those varieties were significantly higher (49.25-59.34 $\mathrm{mg} / 100 \mathrm{~g}$ ), being in the same range to the average values reported from green asparagus. On the other hand, the comparison of the antioxidant activity and chemical composition of green spears from A. acutifolius and $A$. officinalis allowed to conclude that main antioxidants were significantly more abundant in the former. Ascorbic acid was more than fivefold higher (117 vs $23 \mathrm{mg} / 100 \mathrm{~g}$ ) and the content of phenolic compounds was about twice (41.97 vs $27.62 \mathrm{mg} / 100 \mathrm{~g})$. These values correlated to a greater antioxidant capacity of $A$. acutifolius [7]. In consonance with these results, we previously reported that spears of green asparagus from A. officinalis Cv Grande showed lower antioxidant activity linked to poorer contents of total phenolics than those from HT asparagus [37]. These results support the potential use of wild species, which are usually richer in bioactive compounds, for the development of new varieties of green asparagus with improved nutritional and or functional properties. In this context, it has been registered a new variety (HT-801), selected from a breeding program that include several genotypes from both commercial cultivars of A. officinalis and Huétor-Tájar population variety [39]. The distinctive characteristics of this variety include organoleptic attributes that remind to wild species on flavor and texture aspects, as well as agronomic yields similar to those from most cultivated commercial hybrids. Also, its content on bioactive compounds, mainly flavonoids and saponins, are higher than the average values reported for green asparagus cultivars (75.10 $\mathrm{mg} / 100 \mathrm{~g}$ vs $43.70 \mathrm{mg} / 100 \mathrm{~g}$ of flavonoids, and 2.00 $\mathrm{mg} / 100 \mathrm{~g}$ vs $10.00 \mathrm{mg} / 100 \mathrm{~g}$ of saponins respectively).

Some authors have reported that phytochemicals are more influenced by seasonal changes and light than for the cultivation area. In an asparagus trial carried out in two different areas of Japan, Fukushima and Nagano, it was evaluated the influence of the environmental conditions on the content of rutin and total phenolics from green asparagus. The results evidenced that antioxidants were highly influenced by seasonal changes and light. It was found that spears harvested in the summer-autumn period contained less rutin and total phenolics than those from early spring because of low levels of light and UV radiation, both in Fukushima and Nagano [40].

Conversely, other studies suggest that the cultivation area is a determining factor of the chemical composition. Hence, the ascorbic acid contents of 8 different white varieties cultivated in Greece were very similar, varying from 14.10 to $20.19 \mathrm{mg} / 100 \mathrm{~g}$ fresh weight [39]. One of those varieties was Cyprus, whose content was 17.28 $\mathrm{mg} / 100 \mathrm{~g}$, whereas the contents of ascorbic acid for the same variety cultivated in 3 distinct Spanish locations were 21-4 -82 $\mathrm{mg} / 100 \mathrm{~g}$ respectively [28]. In the same line, an investigation on the chemical composition of wild asparagus from Portugal and its comparison with similar samples from different origins, concluded that there were great differences in ascorbic acid contents [8]. So,
Portuguese samples contained $142 \mathrm{mg} / 100 \mathrm{~g}$ of dried sample, which was significant higher than the contents reported from sea-asparagus and cultivated asparagus from China, which contained $50.4 \mathrm{mg} / 100 \mathrm{~g}$ and 49 $\mathrm{mg} / 100 \mathrm{~g}$ respectively $[41,42]$ but slightly lower than cultivated asparagus from USA, which contained $200 \mathrm{mg} / 100 \mathrm{~g}$ [43].

All above referred studies have been made on fresh asparagus. In the present work, we have investigated, for the first time, the composition of different industrial processed samples of asparagus. There have been evaluated nine asparagus components related to nutritional and functional quality, comparing three factors (spear color, size and origin). The results of these comparative studies, which are summarized in Figure 1 and Figure 2, revealed that there were several differences depending on the origin. As it can be observed in Figure 1, the composition of white asparagus from China, Peru and Navarra (Spain) was very similar, and the slight found differences consisting on samples from Peru containing lower contents of proteins and ash, and higher content of sugars in comparison to those samples from China and Navarra (Spain),

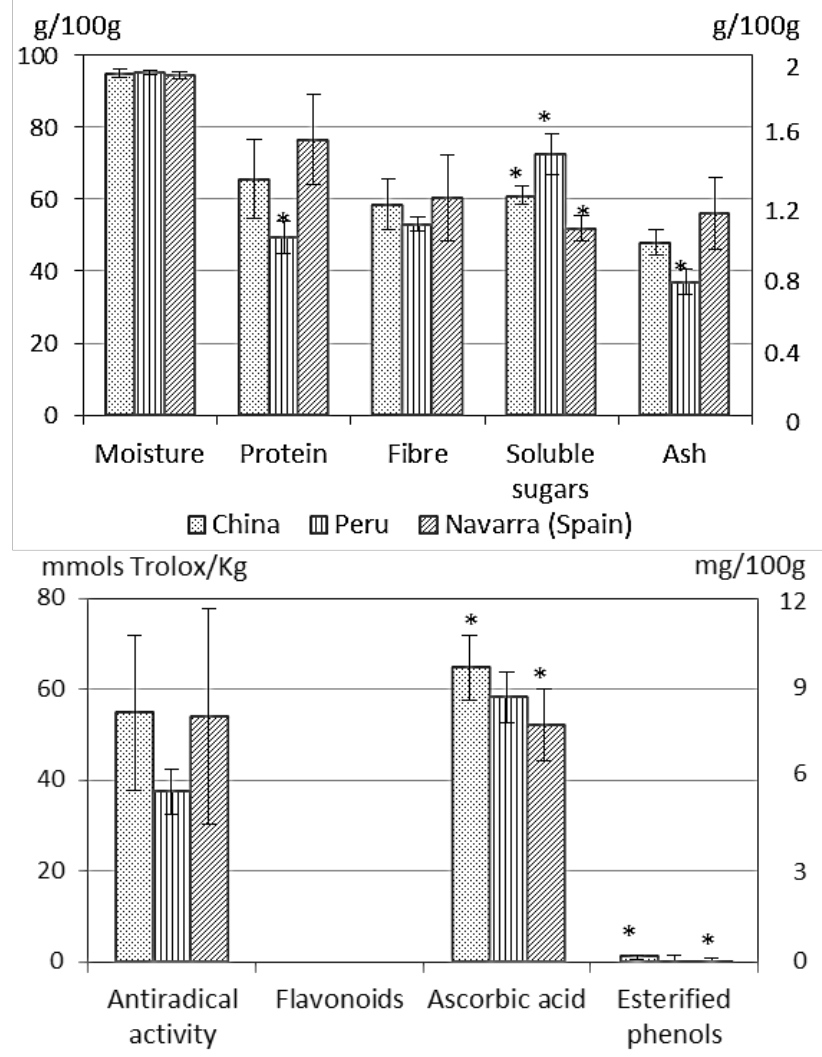

In Subfigure A, the moisture is represented in the primary axis (g/100g) and the rest of components in the secondary one (g/100g). In Subfigure B, the antioxidant capacity is represented in the primary axis (mmols Trolx/Kg), and the phytochemicals in the secondary one (mg/100g) (*Significant differences).

Figure 1. Chemical composition of canned white asparagus versus origin

The composition of green spears for the four investigated origins were also similar, but there were found several differences, being the most remarkable the higher contents of fibre, ash and flavonoids in the samples from Granada (Spain) with respect to the three other origins (Figure 2). 

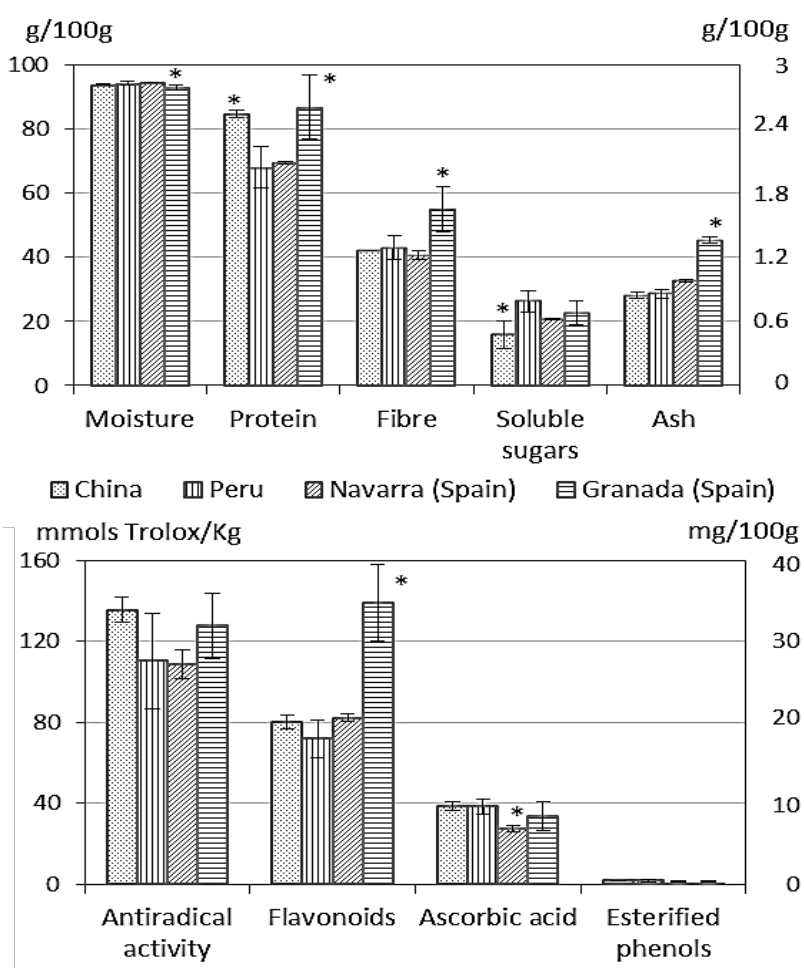

In Subfigure A, the moisture is represented in the primary axis $(\mathrm{g} / 100 \mathrm{~g})$ and the rest of components in the secondary one (g/100g). In Subfigure B, the antioxidant capacity is represented in the primary axis (mmols Trolx/Kg), and the phytochemicals in the secondary one (mg/100g). (*Significant differences).

Figure 2. Chemical composition of canned green asparagus versus origin

In green samples, it can also be evaluated the influence of asparagus variety or cultivar on the spear composition. The ten investigated samples included two different varieties, as samples G9 and G10 corresponded to triguero asparagus from Huétor-Tájar, whereas the eight other samples come from commercial hybrids, most probably Grande cv. In general, these two samples are richer in chemical components and phytochemicals than the eight other samples, being noteworthy their much higher contents of flavonoids. In order to gain further knowledge about the relevance of asparagus variety in both the initial content and the maintenance of these bioactive compounds during processing, we studied in detail the flavonoid profile from the distinct genotypes of green asparagus cultivated in Huétor-Tájar (Granada). The composition of flavonoid glycosides present in Triguero-HT, Grande cv and HT-801 variety is showed in Figure 3. We determined the composition of fresh and processed spears, as well as their brines, and the results evidenced that the processing did not cause significant losses of flavonoids in any of the three samples. As it can be observed in the Figure 3, rutin is the main flavonoid glycoside and represents about $90 \%$ of total flavonoid complement in Triguero-HT and in the Grande cv. On the other hand, even when the total content of flavonoids was equivalent, the qualitative composition of the HT-801 variety is very different to that from the two other samples. In the first place, rutin represents less than $50 \%$ of the total flavonoid complement and it is accompanied by five other flavonoid glycosides, derived of three distinct aglycons, all of them present in both fresh and processed samples. Regarding the balance of individual compounds prior and after processing, it was observed that flavonoid concentration from processed spears plus brines was equal, or even higher, than that from its fresh sample. Rutin content was higher after processing, finding that fresh samples contained $26.2 \mathrm{mg}$ flavonoids/100g and the amounts quantified in the processed ones were $26.4 \mathrm{mg} / 100 \mathrm{~g}$ in the spears plus $5.0 \mathrm{mg} / 100 \mathrm{~g}$ in the brines.

The explanation could be that rutin is a flavonoid di-glycoside (quercetin-3-gluco-rhamnoside) derived from quercetin and it is accompanied by two other quercetin derivatives, quercetin-3-rhamnosyl-rutinoside and quercetin-3-glucosyl-rutinoside that could loss sugars during processing and storage and yield additional rutin.

From all these findings, it can be proposed that genetic and environmental factors can influence the chemical and, mainly, the phytochemical composition of green spears and that those differences existing on fresh samples even determine the composition of the processed ones.

Finally, results of multifactorial ANOVA analysis comparing nine asparagus components and three factors above explained confirmed that origin is the factor that determines to a greater extent the composition of asparagus edible portion (Table 7).

Table 7. Results of Multifactorial ANOVA $(\mathbf{p}<0.05)$ Comparing Nine Asparagus Components and Three Factors, Spear Color (White or Green), Origin (China, Peru, Granada (Spain), Navarra (Spain)), and Diameter (Small $(<8 \mathrm{~mm})$, Medium (8-10 mm), Large (10-15 mm), Extra-Large ( $>15 \mathrm{~mm})$ )

\begin{tabular}{|c|c|c|c|c|}
\hline & Sum of squares & DF & F value & $P$ value \\
\hline \multicolumn{5}{|l|}{ Color } \\
\hline Moisture & 0.323739 & 1 & 0.49 & 0.4903 \\
\hline Protein & 2.39705 & 1 & 40.73 & 0.0000 \\
\hline Dietary fiber & 0.0299497 & 1 & 1.09 & 0.3034 \\
\hline Sugars & 1.50345 & 1 & 159.34 & 0.0000 \\
\hline Ash & 0.0171987 & 1 & 1.40 & 0.2444 \\
\hline Ascorbic acid & 5.52771 & 1 & 3.37 & 0.0718 \\
\hline Flavonoids & 1825.62 & 1 & 484.10 & 0.0000 \\
\hline Esterified phenols & 0.519623 & 1 & 66.66 & 0.0000 \\
\hline Antiox. activity & 0.0154299 & 1 & 43.20 & 0.0000 \\
\hline \multicolumn{5}{|l|}{ Origin } \\
\hline Moisture & 7.78026 & 3 & 3.90 & 0.0170 \\
\hline Protein & 1.813017 & 3 & 10.48 & 0.0000 \\
\hline Dietary fiber & 0.5753512 & 3 & 6.99 & 0.0009 \\
\hline Sugars & 0.673331 & 3 & 23.79 & 0.0000 \\
\hline Ash & 1.20783 & 3 & 32.85 & 0.0000 \\
\hline Ascorbic acid & 31.1939 & 3 & 6.34 & 0.0009 \\
\hline Flavonoids & 1422.7 & 3 & 68.86 & 0.0000 \\
\hline Esterified phenols & 0.0844425 & 3 & 3.61 & 0.0229 \\
\hline Antiox. activity & 0.00200415 & 3 & 1.87 & 0.1532 \\
\hline \multicolumn{5}{|l|}{ Size } \\
\hline Moisture & 3.16267 & 3 & 1.58 & 0.2114 \\
\hline Protein & 0.65002 & 3 & 3.72 & 0.0204 \\
\hline Dietary fiber & 0.0791016 & 3 & 0.96 & 0.4221 \\
\hline Sugars & 0.0678583 & 3 & 2.40 & 0.0852 \\
\hline Ash & 0.137515 & 3 & 3.74 & 0.0200 \\
\hline Ascorbic acid & 2.09169 & 3 & 0.43 & 0.7356 \\
\hline Flavonoids & 156.492 & 2 & 11.36 & 0.0012 \\
\hline Esterified phenols & 0.0244818 & 3 & 1.05 & 0.3844 \\
\hline Antiox. activity & 0.0014059 & 3 & 1.31 & 0.2865 \\
\hline
\end{tabular}



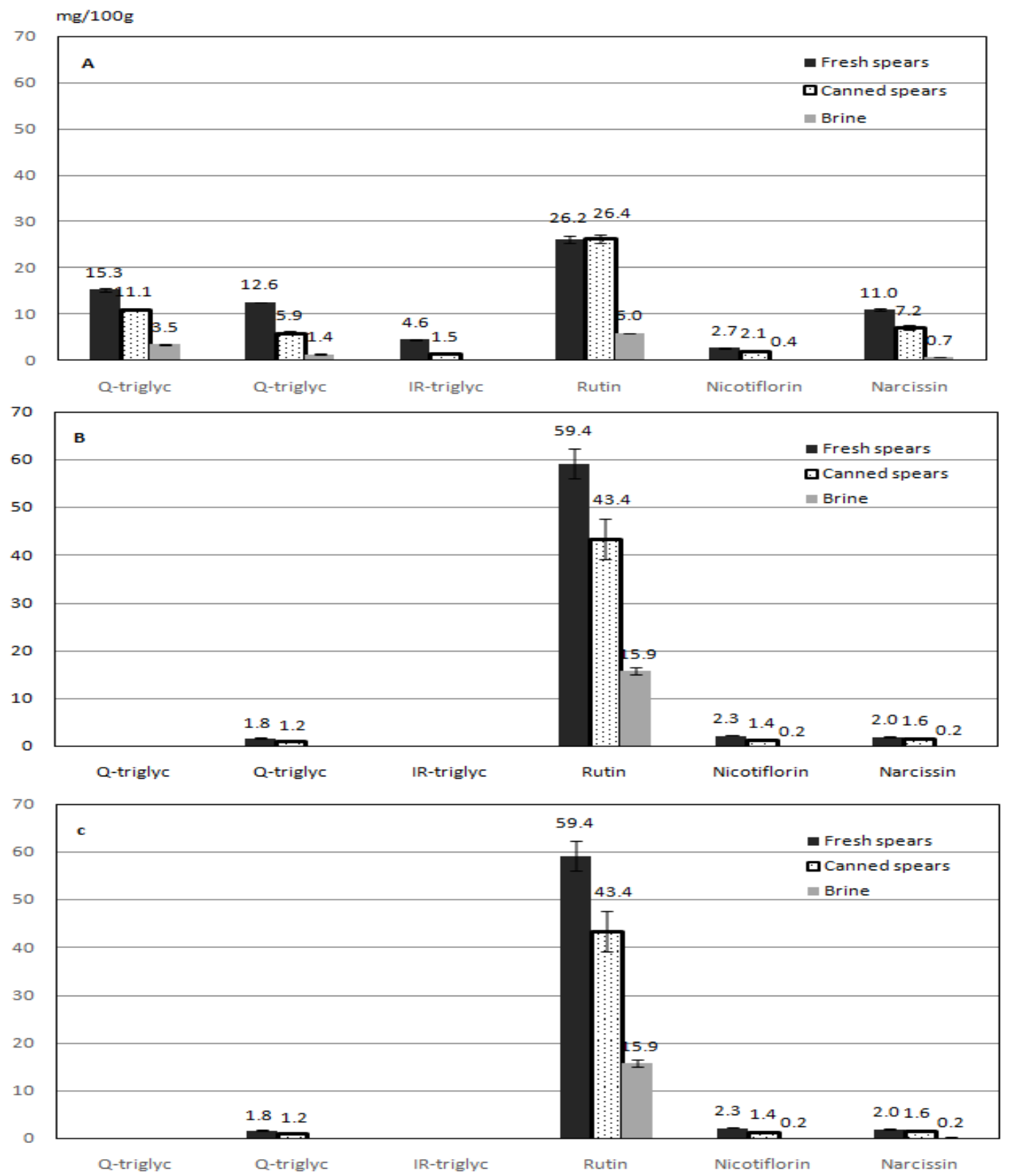

Figure 3. Flavonoid profile of fresh asparagus, canned asparagus and brines from samples of Triguero-HT (A), Grande cv (B) and HT-801 variety (C)

From these comparative analyses it can be established that processed green asparagus are of higher nutritional and functional value than the white ones and that among the green samples there are some of them with a differential chemical composition that gives them a higher quality.

\section{Conclusions}

As it has been above described, practically all the existing bibliography on the influence of different factors in the chemical composition of the asparagus makes reference to the fresh spears, but it is evident that the industrial processing of the spears causes several modifications on both nutritional and phytochemical components that could be more or less accused depending on the asparagus variety and origin among other factors. As far as we know this is the first study on chemical and phytochemical composition of canned asparagus spears, including the most representative samples available in the market. Form our results it can be concluded that:
- Green asparagus are of greater nutritional and functional interest than the white ones

- In general terms, the content of nutrients and phytochemicals of processed asparagus is about half that of fresh asparagus

- Cultivation area may influence the asparagus composition, but asparagus variety seems to be a more determinant factor, being the cultivars more similar to the wild species the most suitable for the development of new varieties of high nutritional and functional value.

As general conclusion, all the studied asparagus samples can be considered nutritionally well-balanced plant-food, which also contained significant amounts of bioactive compounds, mainly antioxidants that confer them an additional value related to beneficial effects on human health. It is remarkable that, among canned vegetables, asparagus spears are one of the best sources of bioactive fiber and antioxidants, such as ascorbic acid and phenolics. Thanks to the most recent advances in optimization of industrial processing, the losses of 
chemical components are being minimized and about $80-90 \%$ of the compounds present in fresh asparagus are recovered from the cooked spears and their processing liquids. Although any type of asparagus results of nutritional and functional interest, the results from the present study evidence that the green spears are richer on interesting compounds than the white ones and, within them, those varieties that preserve wild characteristics occupied the top position of final product quality.

\section{Acknowledgements}

This work was supported by the the Ministerio de Ciencia e Innovación of Spain (AGL2011-29632).

\section{Competing Interests}

The authors have no competing interests.

\section{References}

[1] López, G., Ros, G., Rincón, F., Ortuño, J., Periago, M. J. and Martíneza, M. C. "Amino acids and in vitro protein digestibility changes in green asparagus (Asparagus officinalis, L.) during growth and processing”. Food Res. Int., 29, 617-625, 1996.

[2] Fuentes-Alventosa, J. M., Jaramillo-Carmona, S., RodríguezGutiérrez, G., Guillén-Bejarano, R., Jiménez-Araujo, A., Fernández-Bolaños, J. and Rodríguez-Arcos, R. "Preparation of bioactive extracts from asparagus by-product”. Food Bioprod. Proccess., 91, 74-82, 2013.

[3] USDA National Nutrient Database Report 11012: “Asparagus, cooked, boiled, drained”. Report date: May, 2016.

[4] Vinson, J. A., Hao, Y., Su, X. and Zubik, L. "Phenol antioxidant quantity and quality in foods: vegetables”. J. Agric. Food Chem., 46, 3630-3634, 1998

[5] Pellegrini, N., Serafini, M., Colombi, B., Del Rio, D., Salvatore, S., Bianchi, M. and Brighenti, F. "Total antioxidant capacity of plant foods, beverages and oils consumed in Italy assessed by three different in vitro assays”. J. Nutr., 133, 2812-2819, 2003.

[6] Lai, J. H., Shen, S. C., Chiou, K. M., Lee, Y. H. and Chang, W. H. "Studies on the detinning of canned asparagus. I. Effects of different materials of white and green asparagus on detinning of the canned products". J Chin Chem Soc., 11, 47-54, 1973.

[7] Ferrara, L., Dosi, R., Maro, A., Guida, V., Cefarelli, G., Pacifico, S., Mastellone, C., Fiorentino, A., Rosati, A. and Parente, A. "Nutritional values, metabolic profile and radical scavenging capacities of wild asparagus (A. acutifolius L.)”. J. Food Compos. Anal., 24, 326-333, 2011.

[8] Martins, D., Barros, L., Carvalho, A. M. and Ferreira, I. C. F. R. "Nutritional and in vitro antioxidant properties of edible wild greens in Iberian Peninsula traditional diet”. Food Chem., 125, 488-494, 2011.

[9] Vázquez-Castilla, S., Jaramillo-Carmona, S., Fuentes-Alventosa, J. M., Jiménez-Araujo, A., Rodríguez-Arcos, R., Cermeño-Sacristán, P., Espejo-Calvo, J. A. and Guillén-Bejarano, R. "Saponin Profile of green Asparagus Genotypes”. J. Agric. Food Chem., 61, 11098-11108, 2013.

[10] Chin, C. K. and Garrison, S. A. "Functional elements from asparagus for human health”. Acta Hortic., 776, 219-226, 2008.

[11] Jaramillo, S., Muriana, F. J. G., Guillen, R., Jimenez-Araujo, A., Rodriguez-Arcos, R. and López, S. 2016. "Saponins from edible spears of wild asparagus inhibit AKT, p70S6K and ERK signalling, and induce apoptosis through G0/G1 cell cycle arrest in human colon câncer HCT-116 cells”. J. Food Compos. Anal., 26, $1-10,2016$.

[12] Nijveldt, R. J., van Nood, E., van Hoorn, D. E. C., Boelens, P. G., van Norren, K. and van Leeuwen, P. A. M. 2001. Flavonoids: a review of probable mechanisms of action and potential applications. Am. J. Clin. Nutr., 74, 418-425, 2001.
[13] Cushine, T., and Lamb, A. J. "Antimicrobial activity of flavonoids”. Int. J. Antimicrob. Agents, 26, 343-356, 2005.

[14] Rodríguez-Arcos, R., Smith, A.C. and Waldron, K.W. "Ferulic acid cross-links in asparagus cell walls in relation to texture". $J$. Agric. Food Chem., 52, 4740-4750, 2004.

[15] Jaramillo, S., Rodriguez, R., Jiménez, A., Guillen, R., FernandezBolaños, J. and Heredia, A. "Effects of storage conditions on the accumulation of ferulic acid derivatives in white asparagus cell walls”. J. Sci. Food Agric., 87, 286-296, 2007.

[16] Fuentes-Alventosa, J. M., Jaramillo-Carmona, S., RodríguezGutiérrez, G., Rodríguez-Arcos, R., Fernández-Bolaños, J., Guillén-Bejarano, R., Espejo-Calvo, J. A. and Jiménez-Araujo, A. "Effect of extraction method on phytochemical composition and antioxidant activity of high dietary fibre powders obtained from asparagus by-products”. Food Chem., 116, 484-490, 2009a.

[17] Zhao, Z. H. and Moghadasian, M. H. "Chemistry, natural sources, dietary intake and pharmacokinetic properties of ferulic acid: a review”. Food Chem., 109, 691-702, 2008.

[18] Drinkwater, J. M., Tsao, R., Liu, R., Defelice, C. and Wolyn, D. J. "Effects of cooking on rutin and glutathione concentrations and antioxidant activity of green asparagus (Asparagus officinalis) spears". J. Funct. Foods, 342-353, 2015.

[19] Murcia, M. A., Jiménez, M. A. and Martínez-Tomé, M. "Vegetables antioxidant losses during industrial processing and refrigerated storage”. Food Res. Int., 42, 1046-1052, 2009.

[20] Lee, S. C., Prosky, L. and De Vries, J. W. "Determination of total, soluble and insoluble dietary fiber in foods-Enzymaticgravimetric method, MES-TRIS buffer: Collaborative study". $J$. A.O..AC Int., 75, 395-416, 1992.

[21] Pérez-Galvez A., Hornero-Méndez, D., Mínguez-Mosquera, M. I. "Changes in the Carotenoid Metabolism of Capsicum Fruits during Application of Modelized Slow Drying Process for Paprika Production”. J. Agric. Food Chem., 52, 518-522, 2004.

[22] Hamdi, A., Jaramillo-Carmona, S., Bejic, R. S., Tej, R., Zaoui, S., Rodríguez-Arcos, R., Jiménez-Araujo, A., Kasria, M., Lachaala, M., Bouraouia, N. K. and Guillén-Bejarano, R. "The phytochemical and bioactivity profiles of wild Asparagus albus L. plant”. Food Res. Int., 99, 720-729, 2017.

[23] CODEX STANDARD FOR CERTAIN CANNED VEGETABLES (APPENDIX VII - ANNEXES I to VIII ALINORM 07/30/27). European Community comments on Codex Circular Letter CL 2006/56-PFV. October 2017.

[24] CBI Market Information Database. "The EU market for canned fruit and vegetables”. URL: www.cbi.eu Publication date: October 2009.

[25] Sanz, T., Salvador, A., Jiménez, A. and Fiszman, S. M. "Yogurt enrichment with functional asparaus fibre. "Effect of fibre extraction method on rheological properties, colour, and sensory acceptance”. Eur Food Res. Technol., 227, 1515-1521, 2008.

[26] Fuentes-Alventosa, J. M., Rodríguez-Gutiérrez, G., JaramilloCarmona, S., Espejo-Calvo, J. A., Rodríguez-Arcos, R., Fernandez-Bolaños, J., Guillén-Bejarano, R., and Jiménez-Araujo, A. "Effect of extraction method on chemical composition and functional characteristics of high dietary fibre powders obtained from asparagus by-products”. Food Chem., 113, 665-671, $2009 \mathrm{~b}$.

[27] Makris, D. P. and Rossiter, J. T. "Domestic processing of onion bulbs (Allium cepa) and asparagus spears (Asparagus officinalis): effect on flavonol content and antioxidant status”. J.Agric. Food Chem., 49, 3216-3222, 2001.

[28] Martín-Belloso, O. and Llanos-Barriobero, E. "Proximate composition, minerals and vitamins in selected canned vegetables". Eur. Food Res. Technol., 212, 182-187, 2001.

[29] USDA Branded Food Products Database. Full Report (All Nutrients) 45135618, WHOLE WHITE ASPARAGUS, UPC: 8410465051332. Report Date: August 11, 2017.

[30] USDA Branded Food Products Database. Full Report (All Nutrients) 45136324, WHITE ASPARAGUS, UPC: 8413239002301. Report Date: August 11, 2017.

[31] USDA National Nutrient Database for Standard Reference. Full Report (All Nutrients) 11013, Asparagus, canned, regular pack, solids and liquids. Report Date: June 21, 2016.

[32] USDA National Nutrient Database for Standard Reference. Full Report (All Nutrients) 11015, Asparagus, canned, drained solids. Report Date: August 11, 2017.

[33] Fuentes-Alventosa, J. M., Jaramillo, S., Rodríguez-Gutiérrez, G., Cermeño, P., Espejo, J. A., Jiménez-Araujo, A., Guillén-Bejarano, R., Fernández-Bolaños, J. and Rodríguez-Arcos, R. "Flavonoid 
profile of green asparagus genotypes”. J. Agric. Food Chem., 56, 6977-6984, 2008.

[34] Maeda, T., Kakuta, H., Sonoda, T., Motoki, S., Maekawa, K. Suzuki, T. and Oosawa, K. Differences in antioxidative polyphenols contents of asparagus related to cultivars and seasonal change under various cultural conditions of the mother-fern culture. Acta Hortic., 776, 227-234, 2008.

[35] Takács-Hájos, M. and Zsombik, L. "Total polyphenol, flavonoid and other bioactive materials in different asparagus cultivars". Not. Bot. Horti. Agrobot. Cluj. Napoca, 43, 59-63, 2015.

[36] Rodríguez, R., Jaramillo, S., Rodríguez, G., Espejo, J. A., Guillén, R., Fernández-Bolaños, J., Heredia, A. and Jiménez, A. "Antioxidant activity of ethanolic extracts from several asparagus cultivars”. J. Agric. Food Chem., 53, 5212-5217, 2005.

[37] Guillén, R., Rodríguez, R., Jaramillo, S., Rodríguez, G., Espejo, J. A., Fernández-Bolaños, J. and Heredia, A. "Antioxidants from asparagus spears: Phenolics”. Acta Hortic., 776, 246-254, 2008.

[38] Papoulias, E., Siomos, A. S., Koukounaras, A., Gerasopoulos, D. and Kazakis, E. "Effects of Genetic, Pre- and Post-Harvest Factors on Phenolic Content and Antioxidant Capacity of White
Asparagus Spears”. Int. J. Mol. Sci., 10, 5370-5380, 2009.

[39] Moreno, R., Castro, P., Rubio, J., Rodriguez-Arcos, R. and Gil, J. 2012. "Desarrollo de una nueva variedad de espárrago octoploide 'HT801'”. Mejora Genetica Vegetal, 60, 105-108, 2012.

[40] Maeda, T., Honda, K., Sonoda, T., Motoki, S., Inoue, K., Suzuki, T., Oosawa, K. and Suzuki, M. "Light condition influences rutin and polyphenol contents in asparagus spears in the mother-fern culture system during the summer-autumn harvest”. JPN. SOC. HORTIC. SCI., 79, 161-167, 2010.

[41] Shou, S., Lu, G. and Huang, X. "Seasonal variations in nutritional components of green asparagus using the mother fern cultivation”. Sci. Hortic., 112, 251-257, 2007.

[42] Lu, D., Zhang, Z., Wang, S., Cai, J., Zhou, X. and Zhu, C. "Nutritional characterization and changes in quality of Salicornia bigelovii Torr. during storage”. LWT - Food Sci. Technol., 43, 519-524, 2010.

[43] Nindo, C. I., Sun, T., Wang, S. W., Tang, J. and Powers, J. R. "Evaluation of drying technologies for retention of physical quality and antioxidants in asparagus (Asparagus officinalis, L.)”. Lebenson Wiss Technol., 36, 507-516, 2003.

C The Author(s) 2019. This article is an open access article distributed under the terms and conditions of the Creative Commons Attribution (CC BY) license (http://creativecommons.org/licenses/by/4.0/). 